\begin{tabular}{ll}
\hline \hline MINING AND METALLURGY INSTITUTE BOR & ISSN: 2334-8836 \\
& UDK: 622 \\
\hline \hline
\end{tabular}

Vedran Kostic , Zoran Vaduveskovic ${ }^{*}$

\title{
COMPARATIVE OPTIMIZATION OF MINING THE KRAKU BUGARESKU CEMENTATION DEPOSIT USING WHITTLE AND NPV SCHEDULER SOFTWARE
}

\section{Abstract}

The paper is aimed to present a method of determining the final pit contour with maximum discounted profit, to determine the stages of excavation (Pushbacks) and mining schedule for the final pit using the software packages for strategic planning of open pit mining - Whittle and NPV Scheduler, in the case of optimization the Kraku Bugaresku Cementation deposit. In both cases the same techno economic parameters were used and the same initial topography. The aim or intention of the authors was not to judge or advertise the aforementioned software packages, but to demonstrate the optimization procedure in a specific case, with reference to the basic differences. Comparison of the obtained results is also a verification of correctness of the optimization results.

Keywords: optimization, optimal pit contour, pushbacks, mining schedule, software, NPV

\section{INTRODUCTION}

The "Cerovo" deposit is located in the ore field Mali Krivelj - Cerovo, about fif-

teen kilometers northwest of the town of Bor.

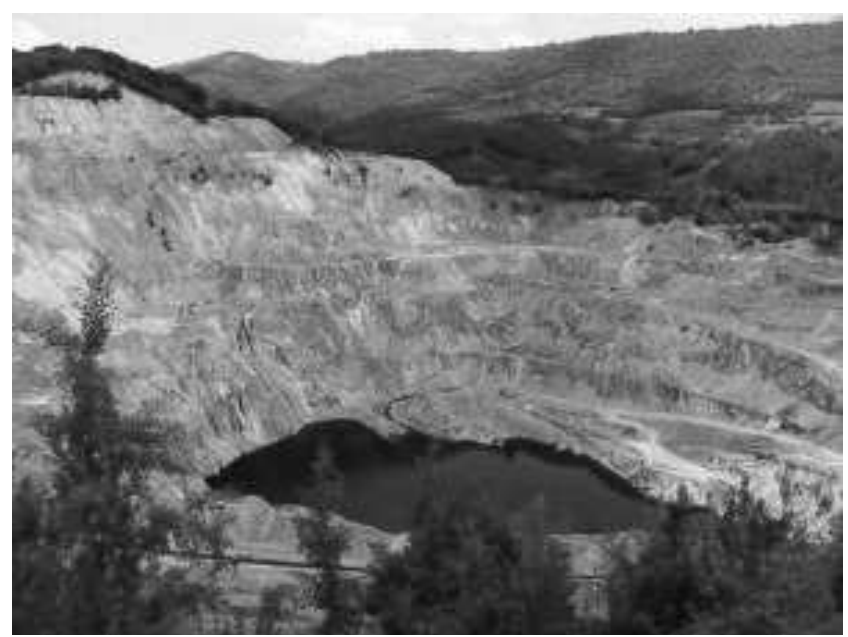

Figure 1 Cerovo Cementation 1

* Mining and Metallurgy Institute Bor, Serbia 
There are the following ore bodies on the site: "Cerovo - Cementation 1", "Cerovo Cementation 2", "Cerovo - Cementation 3", "Cerovo - Cementation 4", "Drenova" and "Cerovo - Primary".

In 1990, the work began at the opening the open pit Cementation 1, and the prestripping period was dictated by the length of investment period for construction the facilities of Flotation Plant and hydrotransport system for ore pulp to the Flotation Plant in Bor, i.e. the infrastructure facilities of the mine. This period lasted more than 2 years. The Kraku Bugaresku Cementation deposit is a cementation zone of the secondary enrichment and the main oxide minerals are azurite, malachite, and even native copper as occurrence. The main holder of copper bearing mineralization of sulfide minerals is chalcopyrite accompanied by bornite, since pyrite is the most present mineral in the ore. Chalcocite, covellite and azurite are also presented to a lesser extent. [9]

The main problem with the Kraku Bugaresku Cementation deposit is a significant participation of oxide minerals in total ore what reduces the copper recovery in the flotation process of concentrate preparation, and by that the final effects of valorization the total production. In the process of flotation concentration, higher copper recovery can be achieved in the processing of sulfide ore than it is the case in processing of oxide ore. [7] In the world today, the hydrometa- llurgical processing technology, leaching and SX/EW (solvent extraction and electrochemical separation by electrowinning) are successfully used for the processing of oxide ores, which is particularly actual for low grade heaps like dumps or specially formed oxide ore heap piles. $[4,5]$ The leachingSX/SW technology implies that copper from heap is recovered with a solution of sulfuric acid which, after the percolation through the pile, is collected, purified and, in the process of solvent extraction the copper ions are transferred from aqueous into organic phase. The aqueous phase is returned to the leaching process while the organic phase is sent to the process of re-extraction, where in copper is transferred into copper-sulfate solution from which it is further recovered in the process of electro-winning. The resultant copper cathode purity is $99.99 \% \mathrm{Cu}$. [5]

In order to test the possibility and effects of two methods of processing ore at the deposit Kraku Bugaresku Cementation, it was necessary to revise the block model in the software GEOVIA Gems to clearly separate the zone of sulfide and oxide ore and enable optimization in the case of two processing methods, i.e. flotation of sulfide (Mill) ore and leaching of oxide ore (Leach). Therefore, the deposit Cerovo Cementation is a separate zone of sulfide ore with participation of oxide minerals by $10 \%$ and the oxide ore zone with participation of oxide minerals higher than $10 \%$.

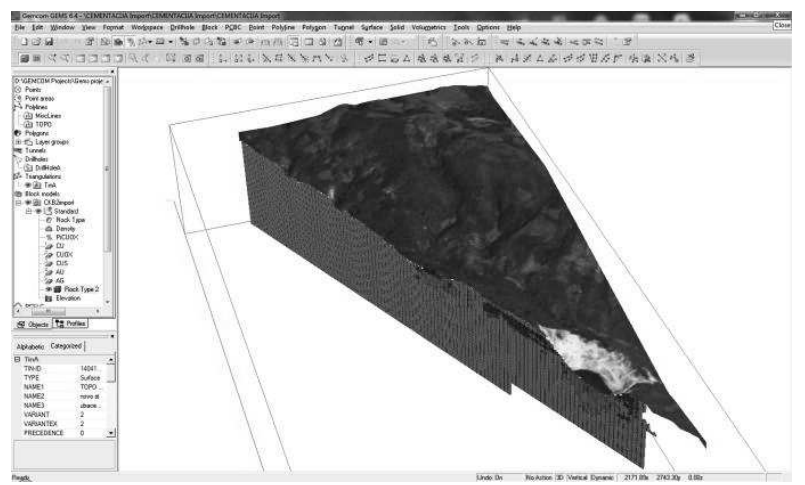

Figure 2 View of a block model in GEMS with an oxide (red) and sulfide (green) ore zones 


\section{Description the Software Packages}

\section{Whittle and NPV Scheduler}

Software packages Whittle from the company GEOVIA and NPV Scheduler (NPVS) from the company DATAMINE, are used for strategic planning in the open pit mining, in determining the optimal open pit contour, selection of appropriate open pit mine stages (Phases-Pushbacks) and defining the mining schedule in order to achieve the optimum techno-economic parameters and improved financial results (Figure 3).

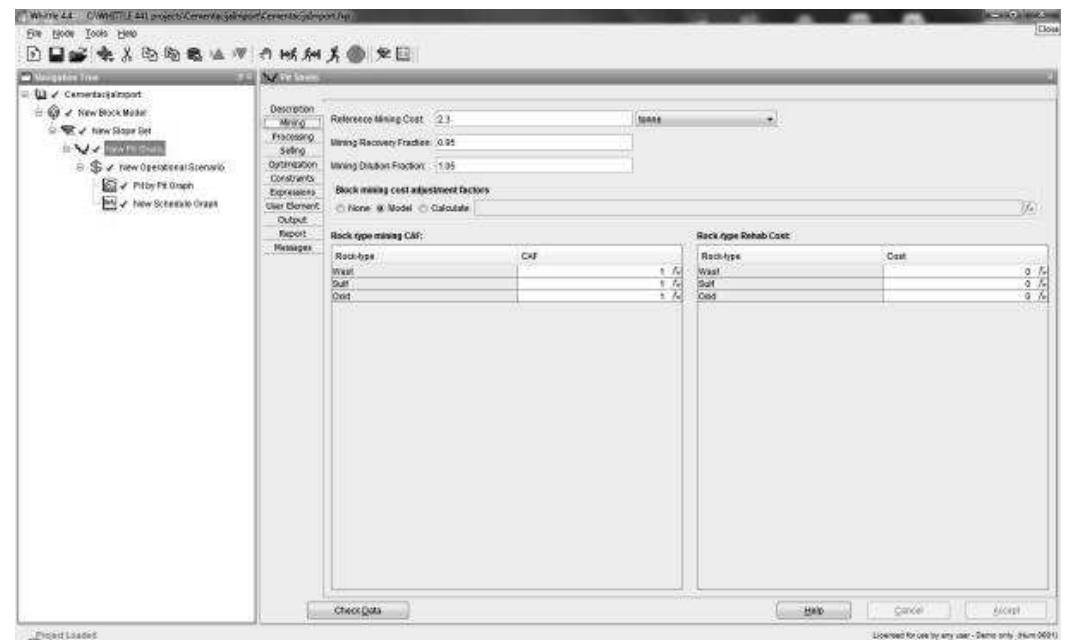

a.

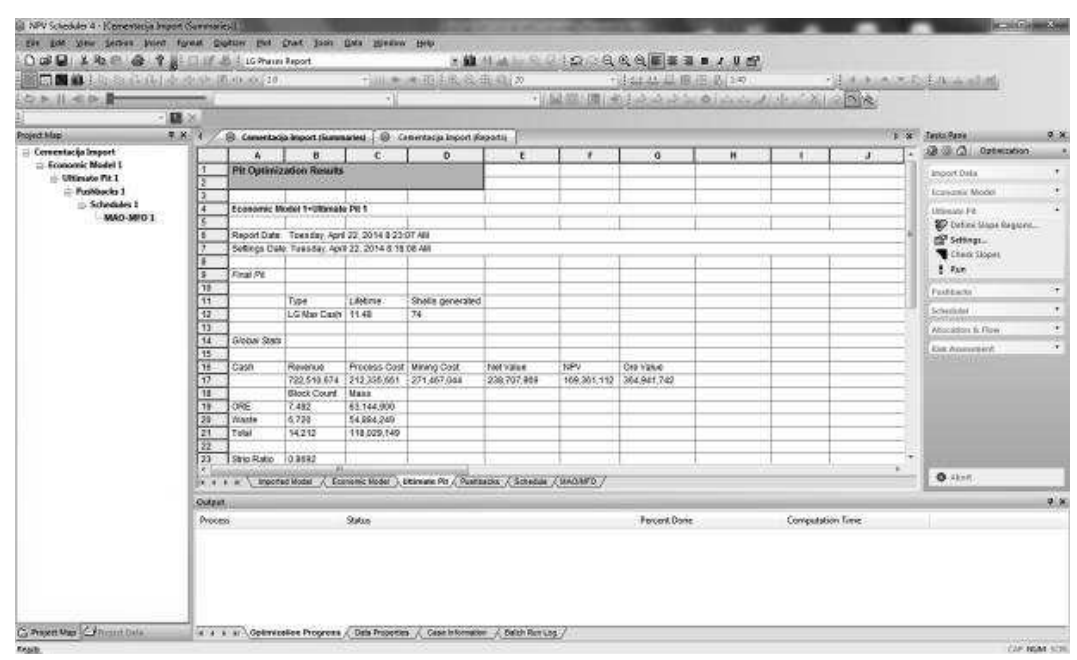

$b$.

Figure 3 "Windows" of Whittle (a) and NPVS (b) software 
Input Data for Determining the Final Pit Contour and Mining Schedule

The scenario considered in this work involves limited processing of sulfide ore in the flotation (Mill) with maximum of $2.5 \mathrm{mt} /$ year in the first two years, with the expansion of the flotation processing capacity to $5.5 \mathrm{mt} /$ year in the coming years. Processing of oxide ore by leaching (Leach) would not be limited annually, but would be adapted to the amounts of oxide ore that must be excavated within the total excavated rock as to allow for excavation of necessary amounts of sulfide ore for the planned capacity of flotation processing (2.5 mil.t or 5.5 mil.t). Table 1 shows the input economictechnological parameters used as the basis for the optimization process in both softwares. [1]

Table 1 Input parameters for optimization in Whittle and NPVS

\begin{tabular}{|l|r|}
\hline Economic cut-off grade of copper & $\mathbf{0 . 1 5 \%} \mathbf{C u}$ \\
\hline Metal prices & $5000 \$ / \mathrm{t}$ \\
\hline copper & $30000 \$ / \mathrm{kg}$ \\
\hline gold & $400 \$ / \mathrm{t}$ \\
\hline silver & $2.3 \$ / \mathrm{t}$ \\
\hline Mining costs & $4 \$ / \mathrm{t}$ \\
\hline Mineral processing costs & 1 \$/t \\
\hline flotation (Mill) & $450 \$ / \mathrm{t}$ \\
\hline leaching (Leach) & $100 \$ / \mathrm{t}$ \\
\hline Additional copper recovery costs & $150 \$ / \mathrm{kg}$ \\
\hline flotation & $15 \$ / \mathrm{kg}$ \\
\hline leaching & $95 \%$ \\
\hline Additional metal recovery costs & $5 \%$ \\
\hline gold & \\
\hline silver & $78.8 \%$ \\
\hline Mining recovery & $75 \%$ \\
\hline Dilution from mining & $50 \%$ \\
\hline Metal recoveries & $40 \%$ \\
\hline copper (flotation and metallurgical treatment) & $10 \%$ \\
\hline copper (leaching and SX/EW) & $37{ }^{\circ}$ \\
\hline gold (in both processes) & \\
\hline silver (in both processes) & \\
\hline Discount rate & \\
\hline Slope angle of open pit & \\
\hline
\end{tabular}

Mining layout as of 01. 04. 2014 was taken for the initial topography.

\section{Selection the Optimal Open Pit Contour and Phase Determining}

Both softwares are based on the LerchGrossman optimization algorithm. The essence of this algorithm is that, for a given techno-economic parameters, the most eco nomical open pit contour is formed by movement from the lowest acceptable economic block to the highest block in the model, while respecting the defined pit slope angles. In order to determine the most economical direction of open pit development, and determination the appropriate stages when planning a mine schedule, software have an option of scaling the metal prices using a coefficient (revenue factor) 
resulting in a series of pits (nested pits) from the smallest (for the lowest price of metal) to the largest (depending on the increase of metal price). [2, 3, 4] Open pit with the coefficient of 1.0 (100\% revenue factor) is an open pit with unscaled selling price of metal. For selection the optimal open pit contour, in this case the pit contour with maximum discounted profit or NPV (net present value), it is necessary to determine the discount rate and define the annual production of ore.

In the Whittle software, NPV values are estimated based on the so-called Best Case and Worst Case Scenarios. The Best
Case scenario is where the final pit is mined through all previously defined stages, one by one, in the form of pushbacks. The Worst Case is a scenario in which the final pit is mined without pushbacks, i.e.by benches within the final pit. These cases are uneconomical (Worst Case) and technologically unattainable in practice (Best Case), and therefore it is necessary to seek the adequate phases and, for them, the optimal final pit. In Whittle, this is referred to as the Specified Case. [8]

Figures 4 and 5 show the graphs for estimated NPV values in Whittle and NPVS.

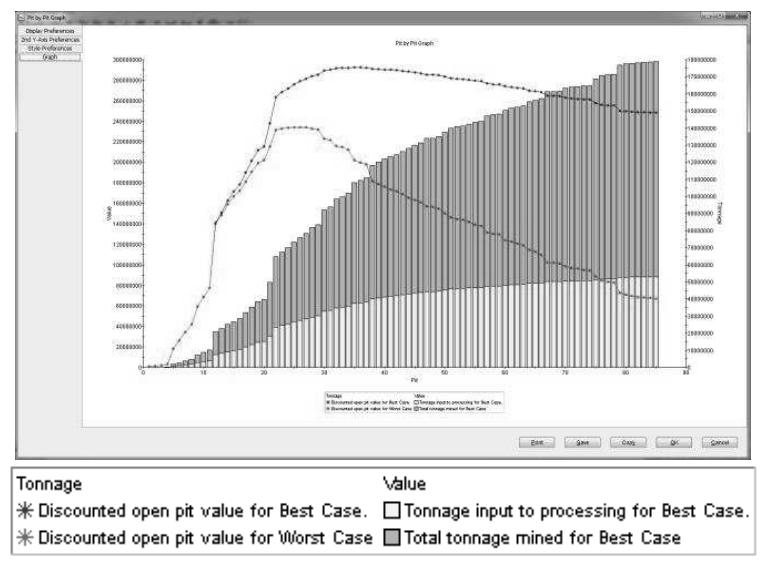

Figure 4 NPV estimation "Pit by Pit graph" in Whittle

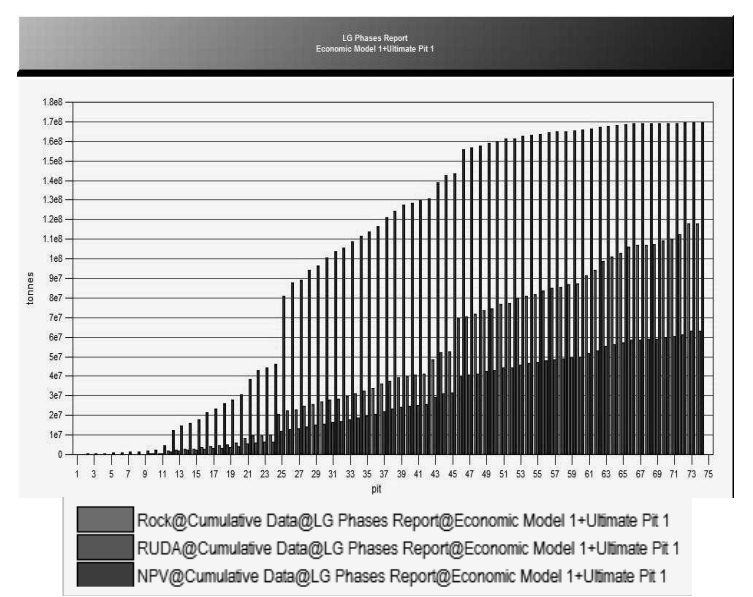

Figure 5 NPV estimation for open pits in NPVS 
In order to facilitate the comparison of optimization results, it was necessary to select approximately the same pit contours for pushbacks and the final pit. Since the "Pit by Pit" for the Best Case of optimization gives the result of the best NPV value for an open pit with the revenue factor of $0.98(98 \%)$, the open pit with the same revenue factor was also chosen as the final pit in NPVS. As pushbacks, the pits with revenue factors $62 \%$ (the first pushback) and $80 \%$ (the second pushback) were selected in both softwares. Table 2 and Figure 6 show the amounts of rock and ore in selected pushbacks and the final pit.

Table 2 Amounts of rock and ore excavated in pushbacks and the final pit in Whittle and NPVS software

\begin{tabular}{|c|c|c|c|c|c|c|c|}
\hline Software & $\begin{array}{c}\text { Phase } \\
\text { (Push- } \\
\text { back) }\end{array}$ & $\begin{array}{l}\text { Revenue } \\
\text { factor }\end{array}$ & $\begin{array}{c}\text { Total exca- } \\
\text { vation }\end{array}$ & Oxide ore & Sulfide ore & Total ore & $\begin{array}{l}\text { Stripping } \\
\quad \text { ratio }\end{array}$ \\
\hline Whittle & \multirow{2}{*}{1} & \multirow{2}{*}{$62 \%$} & 33426102 & 10782047 & 9123921 & 19905968 & 0.68 \\
\hline NPVS & & & 33839437 & 10968750 & 9396337 & 20365087 & 0.66 \\
\hline Whittle & \multirow{2}{*}{2} & \multirow{2}{*}{$80 \%$} & 80698683 & 20605505 & 25339518 & 45945023 & 0.76 \\
\hline NPVS & & & 80999662 & 20823750 & 25602075 & 46425825 & 0.74 \\
\hline Whittle & \multirow{2}{*}{3} & \multirow{2}{*}{$98 \%$} & 117459790 & 26686638 & 35720999 & 62407636 & 0.88 \\
\hline NPVS & & & 112228874 & 25920000 & 35326462 & 61246462 & 0.83 \\
\hline
\end{tabular}

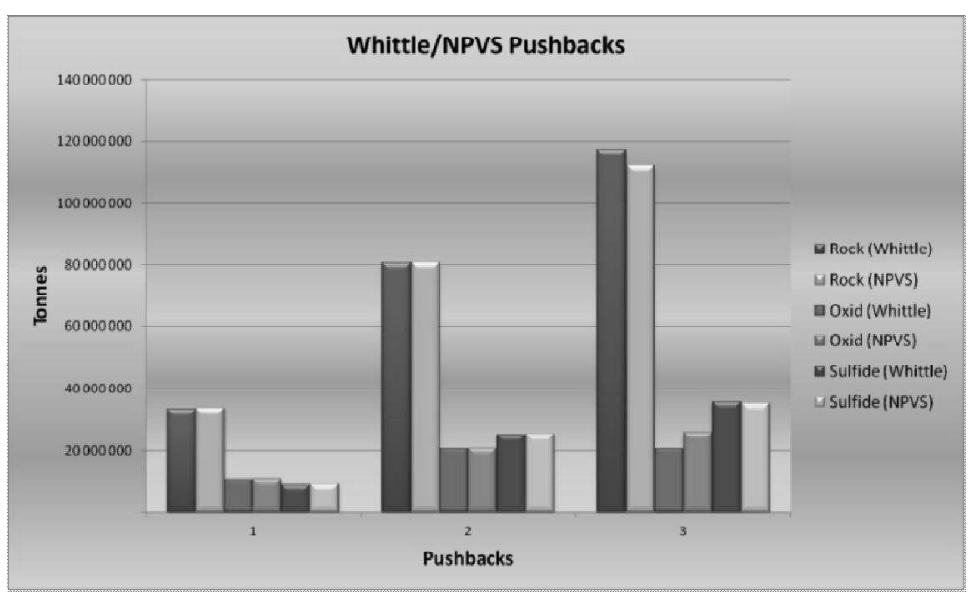

Figure 6 Comparative review of rock and ore amounts in Whittle and NPV Scheduler pushbacks

As it can be seen from Table 2 and Figure 6 , the only noticeable difference is in total amounts of rock and oxide ore in the third phase, i.e. the final open pit. This can be explained by different approximation procedure of pit slope angle. In Whittle, pit slope angle is approximated across a number of benches, while in the NPVS this is achieved through so-called filters in the $\mathrm{X}$ and $\mathrm{Y}$ directions. In Whittle, the default value of 8 benches was adopted as a filter to approximate the pit slope angle. In NPVS, thanks to the Check Slope option, the accuracy of pit slope angle approximation was checked and the filter value was adopted at 17. From the above mentioned reasons, the final pit in NPVS, although with smaller amounts of total ore, also has sma-ller amounts of overburden and therefore more favorable stripping ratio. Figure 7 presents the open pit contours for the revenue factor of $0.98(98 \%)$ in Whittle and NPVS. 


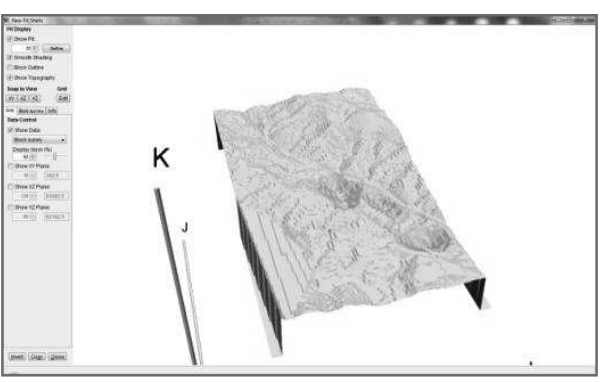

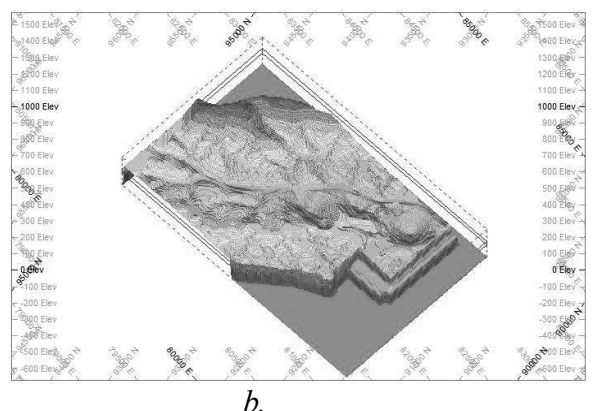

$b$.

Figure 7 The final open pit contour (revenue factor 98\%): $a$-contour in Whittle; $b$-contour in NPVS

\section{Defining the Mining Schedule}

Noticeable difference in the application of these two programs is in the procedure of determining the mining schedule.

Determining the mining schedule in Whittle implies the mining and ore processing limit. In this case, the program defines the schedule by achieving the first limit (either mining or processing). With the $M i$ lawa Balanced option, it is possible to balance the amount of overburden to be mined per years and, thus determine the appropriate mining schedule that will follow the ore processing limit as close as possible while maintaining the constant mining limit. The mining schedule, obtained in Whittle, is shown in Table 3 and Figure 8.

Determining mining schedule in NPVS allows for the "primary" limit (target) for ore processing and "secondary" limit (tracking), i.e. maintaining the total amount of rock mined per years, to define the mining schedule that follows the primary limit exactly, but also just closely maintains the total rock. The program tries to find the ideal scenario and when unable to find it, it begins to gradually relax the secondary limit until the primary objective is achieved, i.e. the "target" limit. The resulting mining schedule obtained in NPVS-in is shown in Table 4 and Figure 9.

The mining schedules shown in Tables 3 and 4 were obtained in the case of mining the final pit in three stages, i.e. two pushbacks and the final pit, and with limited mining and sulfide ore processing capacities. In both cases, a possible scenario for a mining schedule is achieved, which, if necessary, could be modified changing the selected or introducing the additional pushbacks or changing the limits.

Table 3 Mining schedule in Whittle

\begin{tabular}{|c|c|c|c|c|c|c|c|c|c|}
\hline $\begin{array}{c}\text { Year/ } \\
\text { Period }\end{array}$ & Rock & Oxide ore & $\begin{array}{c}\text { Input } \\
\text { to } \\
\text { Leach }\end{array}$ & $\begin{array}{c}\text { Sulfide } \\
\text { ore }\end{array}$ & $\begin{array}{l}\text { Input to } \\
\text { Mill }\end{array}$ & Total ore & Waste & $\begin{array}{c}\text { Stripping } \\
\text { ratio }\end{array}$ & $N P V$ \\
\hline & $t$ & $t$ & $\mathrm{Cu} \%$ & $t$ & $\mathrm{Cu} \%$ & $t$ & $t$ & & $\$$ \\
\hline 1 & 17000000 & 3719981 & 0.24 & 1111045 & 0.37 & 4831026 & 12168974 & 2.52 & 4836966 \\
\hline 2 & 17000000 & 4792264 & 0.31 & 2496350 & 0.45 & 7288615 & 9711385 & 1.33 & 40597954 \\
\hline 3 & 17000000 & 4068033 & 0.23 & 5499785 & 0.36 & 9567818 & 7432182 & 0.78 & 41462231 \\
\hline 4 & 17000000 & 6350167 & 0.21 & 5283643 & 0.29 & 11633810 & 5366190 & 0.46 & 35248060 \\
\hline 5 & 17000000 & 1666371 & 0.20 & 5422840 & 0.28 & 7089211 & 9910789 & 1.4 & 8107899 \\
\hline 6 & 17000000 & 4368596 & 0.20 & 5499436 & 0.23 & 9868032 & 7131968 & 0.72 & 15347140 \\
\hline 7 & 10053699 & 1551532 & 0.18 & 5500000 & 0.23 & 7051532 & 3002167 & 0.43 & 8416079 \\
\hline 8 & 5406091 & 169693 & 0.19 & 4907900 & 0.24 & 5077594 & 328498 & 0.06 & 9271679 \\
\hline Total & 117459790 & 26686637 & & 35720999 & & 62407638 & \begin{tabular}{|l|l|}
55052153 \\
\end{tabular} & 0.88 & 163288008 \\
\hline
\end{tabular}




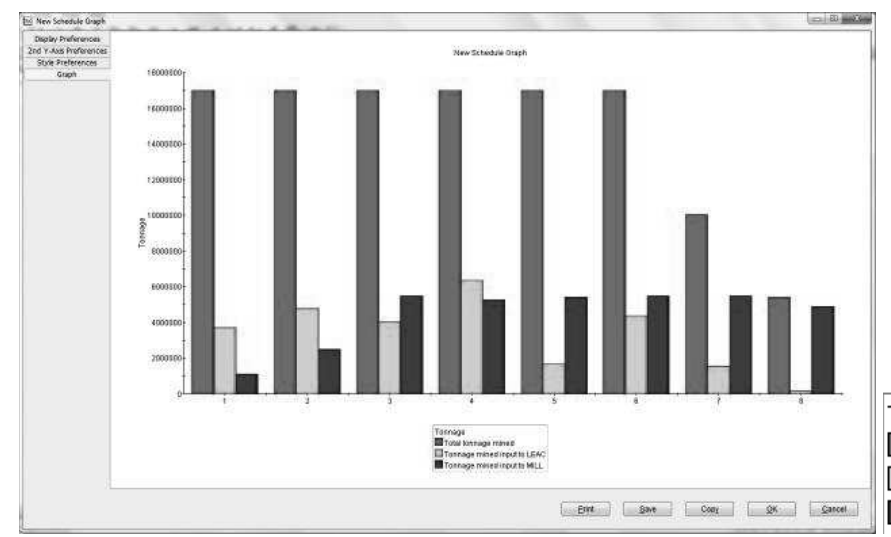

Tonnage

$\square$ Total tonnage mined

$\square$ Tonnage mined input to LEAC

$\square$ Tonnage mined input to MILL

Figure 8 Graph of mining schedule in Whittle

Table 4 Mining schedule in NPVS

\begin{tabular}{|c|c|c|c|c|c|c|c|c|c|}
\hline $\begin{array}{l}\text { Year/ } \\
\text { Period }\end{array}$ & Rock & Oxide ore & $\begin{array}{c}\text { Input } \\
\text { to } \\
\text { Leach } \\
\end{array}$ & Sulfide ore & $\begin{array}{l}\text { Input } \\
\text { to Mill }\end{array}$ & Total ore & Waste & $\begin{array}{c}\text { Stripping } \\
\text { ratio }\end{array}$ & $N P V$ \\
\hline & $t$ & $t$ & $\mathrm{Cu} \%$ & $t$ & $\mathrm{Cu} \%$ & $t$ & $t$ & & $\$$ \\
\hline 1 & 17003250 & 3020625 & 0.25 & 1266300 & 0.43 & 4286925 & 12716325 & 2.97 & 1375127 \\
\hline 2 & 16967812 & 4488750 & 0.30 & 2503575 & 0.47 & 6992325 & 9975487 & 1.43 & 3705586 \\
\hline 3 & 16707262 & 4995000 & 0.27 & 5499900 & 0.37 & 10494900 & 6212362 & 0.59 & 52671121 \\
\hline 4 & 16500712 & 6572813 & 0.22 & 5498550 & 0.31 & 12071362 & 4429350 & 0.37 & 40169189 \\
\hline 5 & 13000500 & 1282500 & 0.22 & 5501250 & 0.29 & 6783750 & 6216750 & 0.92 & 13289510 \\
\hline 6 & 13688662 & 2244375 & 0.21 & 5499900 & 0.25 & 7744275 & 5944387 & 0.77 & 11529474 \\
\hline 7 & 13568175 & 3155625 & 0.19 & 5498550 & 0.24 & 8654175 & 4914000 & 0.57 & 10330821 \\
\hline 8 & 4792500 & 160313 & 0.17 & 4058438 & 0.23 & 4218750 & 573750 & 0.14 & 5465836 \\
\hline Total & 112228874 & 25920000 & & 35326462 & & 61246462 & 50982412 & 0.83 & 17188694 \\
\hline
\end{tabular}

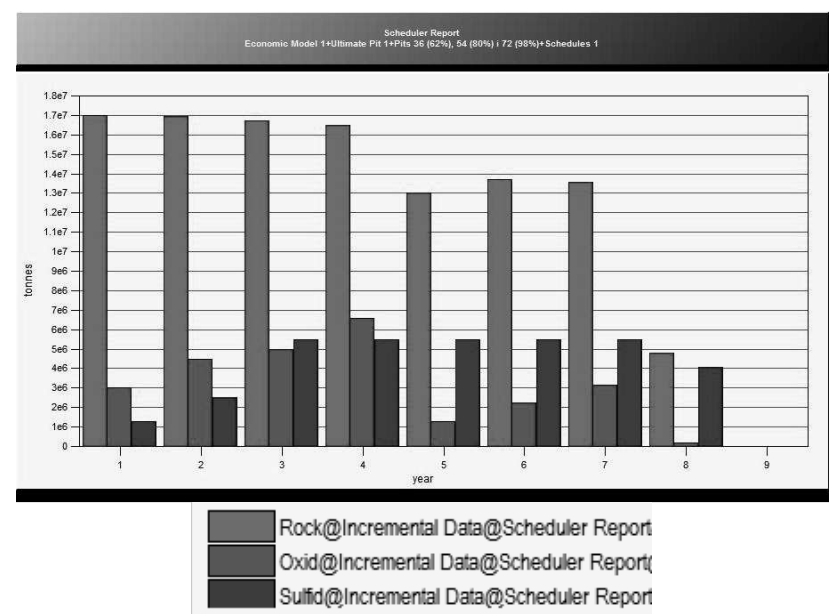

Figure 9 Graph of mining schedule in NPVS 
The difference in approximation the pit slope angle in this software has led to some differences between the amounts of ore and waste rock which caused the software to "choose" somewhat different pit contours as the most economical ones for

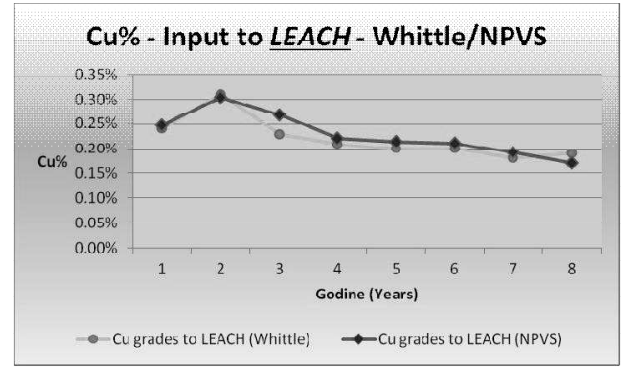

a. selected revenue factors. In addition to the differences in ore amounts for the final pit, this has led to occurrence of difference in the average grades of copper in the mining schedules, as shown in Tables 3 and 4 and Figure 10.

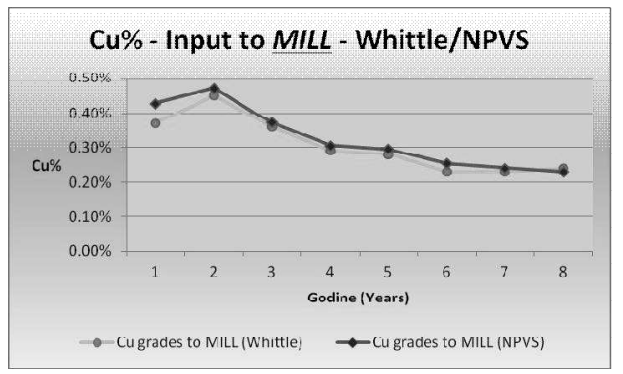

b.

Figure 10 Anual ratio of the average copper grade in the input ore to LEACH (a) and MILL (b) processes for mining schedules in Whittle and NPVS

Table 5 shows the amounts of recovered metals as the final products from Whittle and NPVS final pits. Due to larger amounts of ore and the same technological parame ters of ore processing and metal extraction, slightly higher amounts of final products were obtained in the case of the final pit contours obtained in Whittle software.

Table 5 Amounts of recovered metals from Whittle and NPVS final pit contours

\begin{tabular}{|l|c|c|c|c|c|c|c|c|c|}
\hline \multirow{2}{*}{} & \multicolumn{6}{|c|}{ Oxide (process LEACH) } & \multicolumn{2}{|c|}{ Sulfide (process MILL) } & \multicolumn{4}{c|}{ Total } \\
\cline { 2 - 10 } & $\mathrm{Cu}$ & $\mathrm{Au}$ & $\mathrm{Ag}$ & $\mathrm{Cu}$ & $\mathrm{Au}$ & $\mathrm{Ag}$ & $\mathrm{Cu}$ & $\mathrm{Au}$ & $\mathrm{Ag}$ \\
\cline { 2 - 11 } & $\mathrm{t}$ & $\mathrm{kg}$ & $\mathrm{kg}$ & $\mathrm{t}$ & $\mathrm{kg}$ & $\mathrm{kg}$ & $\mathrm{t}$ & $\mathrm{kg}$ & $\mathrm{kg}$ \\
\hline Whittle & 46337 & 907 & 11335 & 81260 & 1442 & 15838 & $\mathbf{1 2 7 5 9 7}$ & $\mathbf{2 ~ 3 4 9}$ & $\mathbf{2 7 ~ 1 7 3}$ \\
\hline NPVS & 44869 & 875 & 10828 & 80185 & 1419 & 15557 & $\mathbf{1 2 5 0 5 4}$ & $\mathbf{2 2 9 4}$ & $\mathbf{2 6 ~ 3 8 5}$ \\
\hline
\end{tabular}

\section{CONCLUSION}

Due to a different procedure of setting the parameters necessary for optimization, in this case the choice of an appropriate filter or number of benches to approximate the pit slope angle, there was a difference in the ore and rock amounts that led to differences in NPV between these two cases. It might be expected that the pit, although with somewhat smaller amounts of ore, but also with a more favorable stripping ratio, resulted in higher NPV profit. Also, at least in this case, it was shown that an excess of ore in the Whittle final pit has led to reduction in the average grade of copper in the mining schedule in relation to the NPVS final pit, which has further influenced the difference in NPV. Due to relatively small differences, both softwares lead to satisfactory results in terms of the mining schedule. Therefore, one software can be used to verify the results obtained from the other software and, possibly, to improve the mining schedule. 


\section{REFERENCES}

[1] Z. Vaduvesković, N. Vušović, D. Kržanović: Analysis the Possibility of Improving the Economic Indicators of Exploitation the Deposit Cementacija Kraku Bugaresku - Ore Field Cerovo, Mining and Metallurgy Engineering Bor, 1/2014; pp. 13-24

[2] K. Dagdelen, Open Pit Optimization Strategies for Improving Economics of Mining Projects through Mine Planning, $17^{\text {th }}$ International Mining Congress and Exhibition of Turkey IMCET2001, 2001.

[3] A. Hajarian, R. Dambov, R. Karanakova Stefanovska: Long Term Production Scheduling of Sungun Copper Mine Using NPV Scheduler Software, $22^{\text {nd }}$ World Mining Congress and Expo, Istanbul 2011;

[4] M L Smith: Using Milawa/4X as a Starting Solution for Mixed Integer Programming Optimization of Large Open Cut Production Schedules, Strategic Mine Planning Conference, 2001;

[5] M. E. Schlesinger, M. J. King, K. C. Sole, W. G. Davenport: Extractive
Metallurgy of Copper, Fifth Edition, 2011;

[6] G. A. Kordosky: Copper Recovery Using Leach/Solvent Extraction/ Electrowinning Technology: Forty Years of Innovation, 2.2 million tones of copper annually, The Journal of The South African Institute of Mining and Metallurgy, 2002;

[7] K. Lee, D. Archibald, J. McLean, M. A. Reuter: Flotation of Mixed Copper Oxide and Sulphide Minerals with Xanthate and Hydroxamate Collectors, Mineral Engineering, 2008;

[8] Reference Manual, Four-X Strategic Planning Software for Open Pit Mines; Whittle Programming Pty Ltd, 1998;

[9] http://rtb.rs/rtb-bor-doo/rudnik-bakrabor/rudnik-bakra-cerovo/

[10] Z. Vaduvesković, N. Vušović, D. Kržanović: Analysis the Posibility of Improving the Economic Indicators of Exploitation the Deposit Cementacija Kraku Bugaresku - Ore Field Cerovo, Mining and Metallurgy Institute Bor 1/2014, pp 13-24. 


\begin{tabular}{ll}
\hline \hline INSTITUT ZA RUDARSTVO I METALURGIJU BOR & ISSN: 2334-8836 \\
& UDK: 622 \\
\hline \hline
\end{tabular}

Vedran Kostić, Zoran Vaduvesković

\section{UPOREDNA OPTIMIZACIJA OTKOPAVANJA LEŽIŠTA KRAKU BUGARESKU CEMENTACIJA POMOĆU SOFTVERA WHITTLE I NPV SCHEDULER}

\section{Izvod}

Rad ima za cilj da prikaže postupak određivanja konačne konture kopa sa maksimalnim diskontovanim profitom, određivanje faza u otkopavanju kopa (Pushbacks) $i$ dinamike otkopavanja za konačni kop, pomoću softverskih paketa za strateško planiranje površinske eksploatacije - Whittle i NPV Scheduler, na primeru optimizacije ležišta Cerovo Cementacija. U oba slučaja korišćeni su isti tehno ekonomski parametri i isto početno stanje terena. Cilj ili namera autora nije da ocenjuje ili reklamira pomenute softverske pakete već da prikaže proceduru optimizacije na konkretnom primeru, uz osvrt na osnovne razlike. Upoređenje dobijenih rezultata takođe predstavlja i proveru ispravnosti rezultata optimizacije.

Ključne reči: optimizacija, optimalna kontura kopa, faze, dinamika otkopavanja, softver, NPV

\section{UVOD}

Ležište „Cerovo“ nalazi se u rudnom polju Mali Krivelj - Cerovo, petnaestak

kilometara severozapadno od Bora.

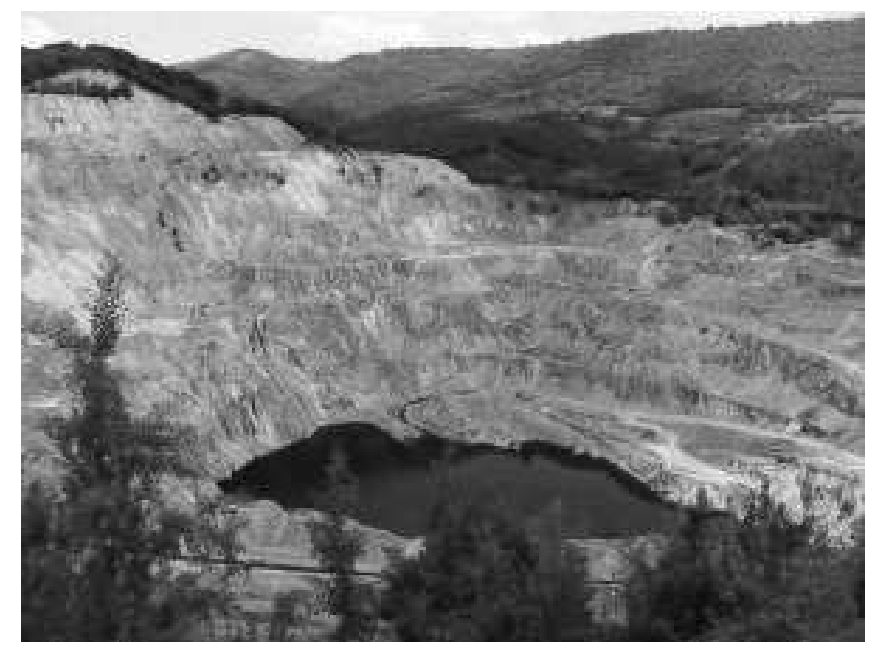

Sl. 1. Cerovo-Cementacija 1

${ }^{*}$ Institut za rudarstvo i metalurgiju Bor 
Na lokalitetu se nalaze rudna tela „Cerovo - Cementacija 1“, „Cerovo - Cementacija 2", „Cerovo - Cementacija 3“, „Cerovo Cementacija 4“, ležište „Drenova“ i „Cerovo - primarno".

Godine 1990. započeti su radovi na otvaranju kopa Cementacija 1, i prestriping period je bio diktiran dužinom trajanja investicionih radova na objektima flotacije i hidrotransporta pulpe do flotacije u Boru, tj. infrastrukturnim objektima rudnika. Taj period je trajao nešto više od 2 godine. Ležište Kraku Bugaresku Cementacija, je cementaciona zona sekundarnog obogaćenja i glavni oksidni minerali su azurit, malahit, čak i samorodni bakar kao pojava. Od sulfidnih minerala glavni nosilac bakronosnog orudnjenja je halkopirit praćen bornitom, dok je pirit najzastupljeniji mineral u orudnjenju. $\mathrm{U}$ manjoj meri zastupljeni su halkozin, kovelin i azurit. [9]

Osnovni problem kod ležišta Kraku Bugaresku Cementacja je u znatnom učešću oskidnih minerala u ukupnoj rudi što smanjuje iskorišćenje bakra u flotacijskom procesu pripreme koncentrata, time i konačne efekte valorizacije ukupne proizvodnje. U procesu flotacijske koncentracije veće iskorišćenje bakra se postiže u preradi sulfidne rude nego što je to slučaj sa preradom oksidne rude. [7] Danas se u svetu za dobijanje bakra iz oksidne rude uspešno prime- njuju procesi hidrometalurške prerade tehnologijom luženja i SX/EW (Solvent extraction and electrowinning, tj. solventna ekstrakcija i elektrohemijsko izdvajanje), što je pogotovu aktuelno kod formiranih gomila sa manjim sadržajem bakra poput jalovišta ili posebno formiranih "haldi" oksidne rude. $[4,5]$ Tehnologija luženje - SX/EW podrazumeva iskorišćenje bakra sa gomile pomoću rastvora sumporne kiseline koja se nakon perkolacije kroz gomilu prikuplja, prečišćava i u procesu solventne ekstrakcije bakarni joni prevode iz vodene u organsku fazu. Vodena faza se vraća u proces luženja dok organska faza odlazi u proces reekstrakcije, gde bakar prelazi u bakarsulfatni rastvor, iz koga se dalje dobija procesom elektrolize. Ovako dobijeni katodni bakar je čistoće 99,99\% Cu. [5]

Da bi se ispitala mogućnost i efekti primene dve metode prerade rude i na ležištu Kraku Bugaresku Cementacija, bilo je potrebno prethodno preraditi blok model $\mathrm{u}$ softveru GEOVIA Gems da bi se jasno razdvojile zone sulfidne i oksidne rude $\mathrm{i}$ omogućila optimizacija za slučaj dve metode prerade, tj. flotiranje sulfidne (Mill) i luženje oksidne rude (Leach). Samim tim, u ležištu Cerovo Cementacija je izdvojena zona sulfidne rude sa učešćem oksidnih minerala do $10 \%$ i zona oksidne rude sa učešćem oksidnih minerala većim od $10 \%$.

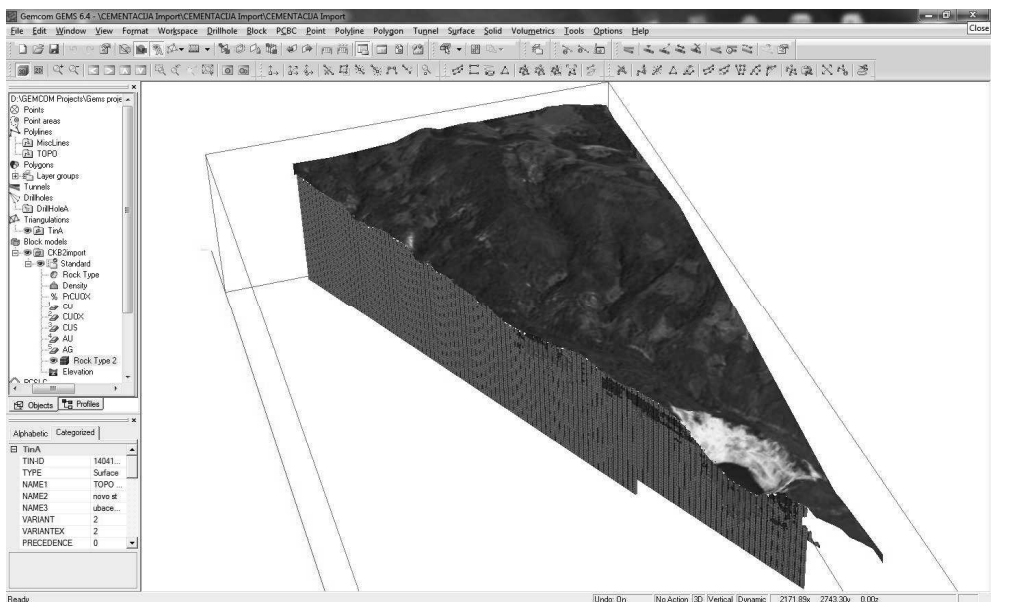

Sl. 2. Prikaz blok modela u GEMSu sa oksidnom (crvena) i sulfidnom (zelena) rudom 
Opis softverskih paketa

\section{Whittle i NPV Scheduler}

Softverski paketi Whittle kompanije GEOVIA i NPV Scheduler (NPVS) kompanije DATAMINE se koriste za strateško planiranje u površinskoj eksploataciji, kod određivanja optimalne konture površinskog kopa, izbora adekvatnih zahvata (FazePushbacks) i definisanja dinamike otkopavanja u cilju ostvarivanja optimalnih tehno-ekonomskih parametara i boljih finansijskih rezulatata (slika 3).

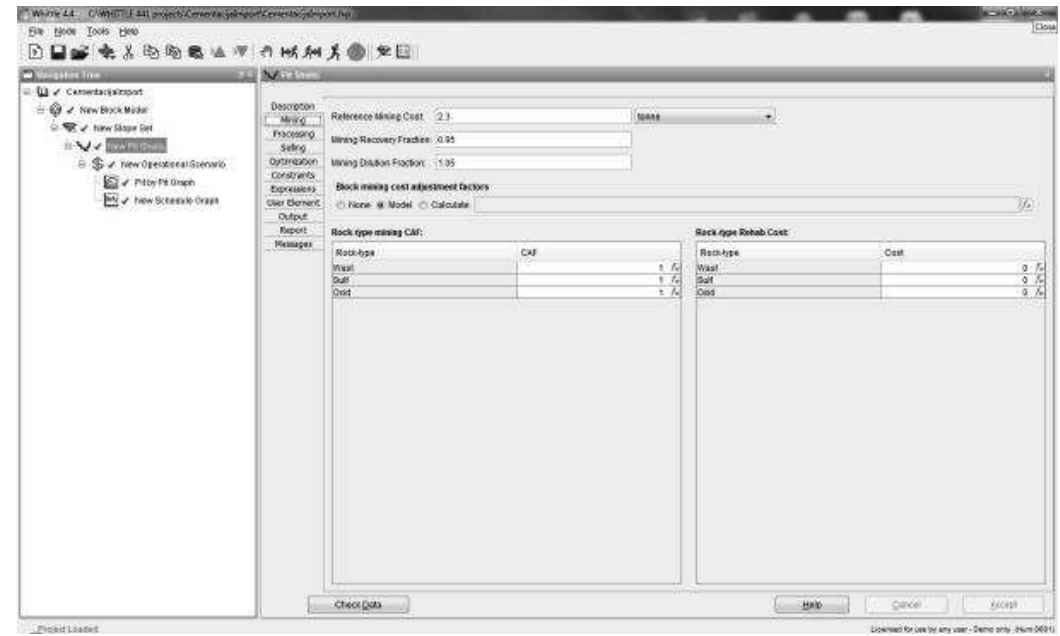

a.

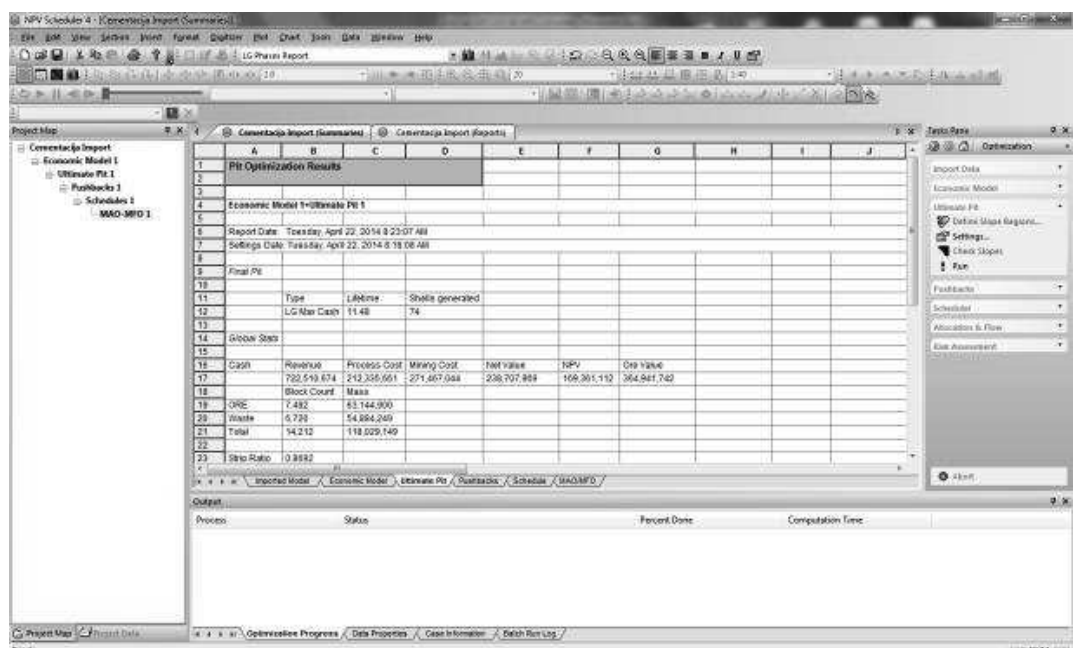

$b$.

Sl. 3. "Prozori" programa Whittle (a) i NPV Scheduler (b) 


\section{Ulazni podaci za određivanje konačne konture kopa i dinamike otkopavanja}

Scenario koji je razmatran u ovom radu podrazumeva limitiranu preradu sulfidne rude u flotaciji (Mill) od maksimalno 2.5 $\mathrm{mt} /$ god $\mathrm{u}$ prve dve godine, sa proširenjem flotacijskog kapaciteta prerade na $5.5 \mathrm{mt} / \mathrm{god}$ u narednim godinama. Prerada oksidne rude luženjem (Leach) ne bi bila limitirana po godinama, već bi se prilagođavala količi- nama oksidne rude koje se moraju otkopati u sklopu ukupnih iskopina, kako bi se omogućilo otkopavanje količina sulfidne rude za planirani kapacitet flotacijske prerade (2.5 mil.t, odnosno 5.5 mil.t). U tabeli 1. prikazani su ulazni ekonomsko-tehnološki parametri koji su poslužili kao osnova u procesu optimizacije u oba softvera. [1]

Tabela 1. Ulazni parametri za optimizaciju u softverima Whittle i NPVS

\begin{tabular}{|c|c|}
\hline Ekonomski granični sadržaj bakra u rudi & $0.15 \% \mathrm{Cu}$ \\
\hline \multicolumn{2}{|l|}{ Cene metala } \\
\hline bakar & $5000 \$ / t$ \\
\hline Zlato & $30000 \$ / \mathrm{kg}$ \\
\hline srebro & $400 \$ / \mathrm{t}$ \\
\hline Troškovi otkopavanja & $2.3 \$ / \mathrm{t}$ \\
\hline \multicolumn{2}{|l|}{ Troškovi pripreme mineralne sirovine } \\
\hline flotiranje (Mill) & $4 \$ / t$ \\
\hline luženje (Leach) & $1 \$ / t$ \\
\hline \multicolumn{2}{|l|}{ Dodatni troškovi dobijanja bakra } \\
\hline kod flotiranja & $450 \$ / \mathrm{t}$ \\
\hline kod luženja & $100 \$ / t$ \\
\hline \multicolumn{2}{|l|}{ Ostali troškovi dobijanja metala } \\
\hline za zlato & $150 \$ / \mathrm{kg}$ \\
\hline za srebro & $15 \$ / \mathrm{kg}$ \\
\hline Iskorišćenje na otkopavanju & $95 \%$ \\
\hline Osiromašenje na otkopavanju & $5 \%$ \\
\hline \multicolumn{2}{|l|}{ Iskorišćenje u procesu dobijanja metala } \\
\hline bakar (flotiranje i metalurška prerada) & $78.8 \%$ \\
\hline bakar (luženje i SX/EW) & $75 \%$ \\
\hline Zlato (u oba procesa) & $50 \%$ \\
\hline srebro (u oba procesa) & $40 \%$ \\
\hline Diskontna stopa & $10 \%$ \\
\hline Ugao boka kopa & $37^{\circ}$ \\
\hline
\end{tabular}

Za početno stanje uzeta je situacija terena na dan 01. 04. 2014. godine.

\section{Izbor optimalne konture površinskog kopa i određivanje faza}

Oba softvera su bazirana na Lerch Grossman algoritmu optimizacije. Suština ovog algoritma je da, za zadate tehnoekonomske parametre, formira najekonomičniju konturu kopa krećući se od najnižeg ekonomski prihvatljivog bloka do najvišeg bloka u modelu, pri tome poštujući definesane uglove kosina kopa. Zbog određivanja najekonomičnijeg pravca razvoja kopa, i određivanje adekvatnih faza $\mathrm{u}$ planiranju otkopavanja, softveri imaju mogućnost skaliranja prodajne cene metala pomoću koeficijenta (revenue factor) čime se dobija serija kopova (nested pits) od najmanjeg (za najnižu prodajnu cenu) do najvećeg (zavisno od uvećanja prodajne cene). [2, 3, 4] Kop sa 
koeficijentom 1.0 (100\% revenue factor) predstavlja kop sa neskaliranom prodajnom metala. Za izbor optimalne konture kopa, u ovom slučaju konture kopa sa maksimalnim diskontovanim profitom ili NPV (net present value) potrebno je odrediti diskontnu stopu i definisati godišnju proizvodnju rude.

U softveru Whittle, NPV vrednosti se procenjuju na bazi tzv. Best Case i Worst Case scenaria. Best Case je scenario u kome se do konačne konture kopa stiže preko otkopavanja etaža svih određenih kontura do konačne u vidu faza (Push-backs). Worst Case predstavlja scenario $\mathrm{u}$ kome se do konačne konture kopa stiže otkopavanjem svih etaža u konačnoj konturi, tj. bez faza. Oba slučaja su, kako neekonomična (Worst Case) tako i tehnološki neostvariva u praksi (Best Case), pa je potrebno tražiti adekvatne faze i, za njih, optimalnu konačnu konturu kopa. U Whittlu se ovo označava kao Specified Case. [8]

Na slikama 4 i 5 prikazani su dijagrami procenjenih vrednosti za NPV u programima Whittle i NPVS

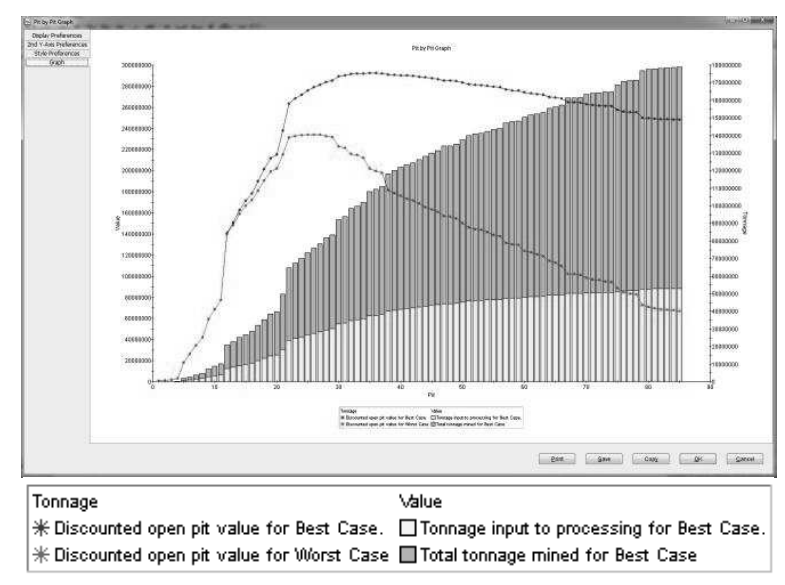

Sl. 4. Procena NPV vrednosti "Pit by Pit graph" u softveru Whittle

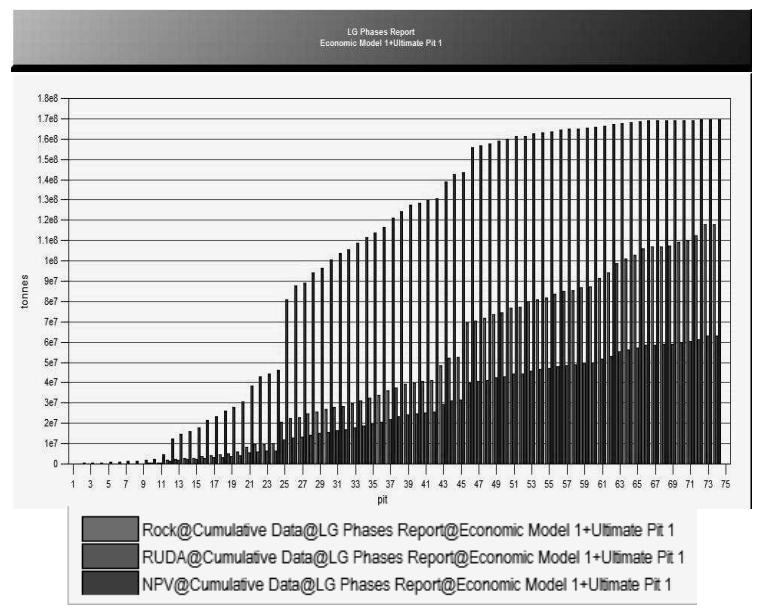

Sl. 5. Procena NPV vrednosti za kopove u softveru NPVS 
Kako bi se omogućilo upoređivanje rezultata optimizacije bilo je potrebno odabrati približno iste konture kopova za faze i za konačnu konturu. Budući da je "Pit by Pit" optimizacija za Best Case kao razultat dala najbolju vrednost NPVa za kop sa revenue faktorom 0.98 (98\%), kop sa istim revenue faktorom je izabran kao konačni kop i u NPVSu. Kao faze, u oba softvera, izabrane su konture kopova za revenue faktore $62 \%$ (prva faza) i $80 \%$ (druga faza). U tabeli 2 i na slici 6 prikazane su količine iskopina $\mathrm{i}$ rude $\mathrm{u}$ izabranim fazama.

Tabela 2. Količine rude i iskopina u fazama i konačnoj konturi u softverima Whittle i NPVS

\begin{tabular}{|c|c|c|c|c|c|c|c|}
\hline Softver & $\begin{array}{c}\text { Faza } \\
\text { (Push- } \\
\text { back) }\end{array}$ & $\begin{array}{c}\text { Revenue } \\
\text { faktor }\end{array}$ & Iskopine & $\begin{array}{l}\text { Oksidna } \\
\text { ruda }\end{array}$ & $\begin{array}{l}\text { Sulfidna } \\
\text { ruda }\end{array}$ & $\begin{array}{c}\text { RUDA } \\
\text { ukupno }\end{array}$ & $\begin{array}{l}\text { Koef. } \\
\text { rask- } \\
\text { rivke }\end{array}$ \\
\hline Whittle & \multirow{2}{*}{1} & \multirow{2}{*}{$62 \%$} & 33426102 & 10782047 & 9123921 & 19905968 & 0.68 \\
\hline NPVS & & & 33839437 & 10968750 & 9396337 & 20365087 & 0.66 \\
\hline Whittle & \multirow[t]{2}{*}{2} & \multirow{2}{*}{$80 \%$} & 80698683 & 20605505 & 25339518 & 45945023 & 0.76 \\
\hline NPVS & & & 80999662 & 20823750 & 25602075 & 46425825 & 0.74 \\
\hline Whittle & \multirow[t]{2}{*}{3} & \multirow{2}{*}{$98 \%$} & 117459790 & 26686638 & 35720999 & 62407636 & 0.88 \\
\hline NPVS & & & 112228874 & 25920000 & 35326462 & 61246462 & 0.83 \\
\hline
\end{tabular}

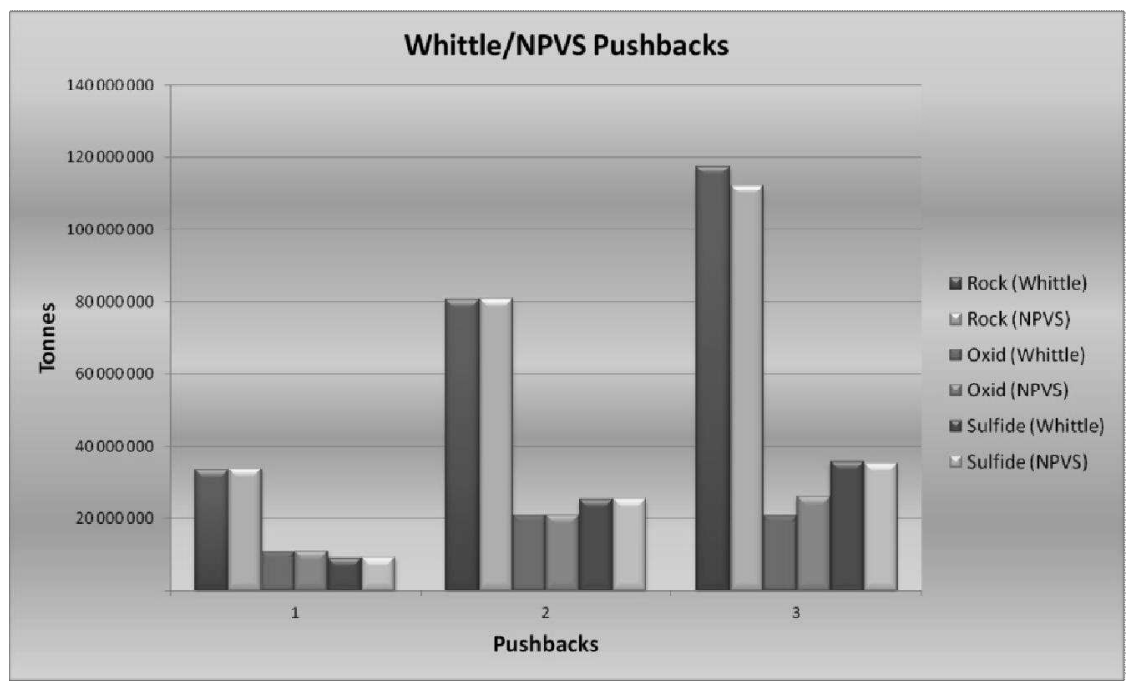

SI. 6. Uporedni prikaz količina rude i iskopina u fazama u softverima Whittle i NPV Scheduler

Kako se to može videti iz tabele 2 , i sa slike 6, jedina primetna razlika je u ukupnim količinama iskopina i oksidne rude za treću fazu, odnosno konačni kop. Ovo se može objasniti različitom procedurom aproksimacije ugla kosine boka kopa. U Whittlu se ugao aproksimira preko broja etaža, dok se u NPVSu to radi preko tzv. filtera po $\mathrm{X}$ i Y pravcima. U Whittlu je usvojena difoltna vrednost od 8 etaža za aproksimaciju ugla kosine kopa. U NPVSu je, zahvaljujući opciji Slope Chek, izvršena provera tačnosti aproksimacije ugla kosine kopa i usvojena vrednost filtera 17 . Iz pomenutog razloga konačna kontura u NPVSu, iako sa manjim količinama rude, ima i manje količine jalovine a samim tim i povoljniji koeficijent raskrivke. Na slici 7 prikazane su konture za revenue factor 0.98 (98\%) u softverima Whittle i NPVS. 

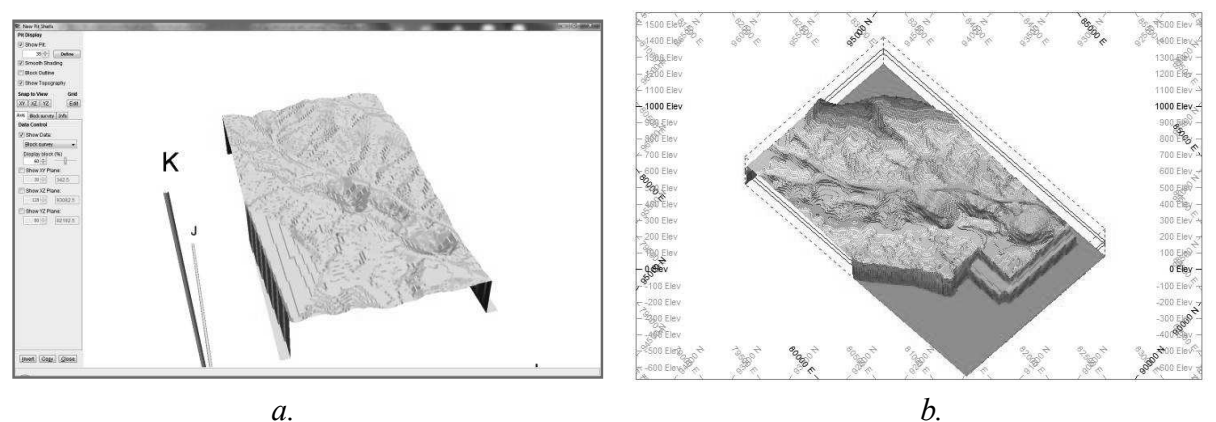

SI. 7. Konačna kontura kopa (Revenue factor 98\%): a - kontura iz Whittla; $b$ - kontura iz NPVSa

\section{Definisanje dinamike eksploatacije}

Primetna razlika u primeni ova dva programa je kod procedure određivanja dinamike otkopavanja.

Određivanje dinamike otkopavanja u Whittle-u podrazumeva uvođenje limita na otkopavanju i u preradi rude. U ovom slučaju program dolazi do dinamike pri dostizanju prvog limita (bilo na otkopavanju ili preradi). Uz opciju Milawa balanced moguće je uravnotežiti količine jalovine koje se otkopavaju po godinama i time odrediti adekvatnu dinamiku otkopavanja koja najpribližnije moguće prati limit na preradi rude uz konstantan limit na otkopavanju. Dinamika dobijena $u$ Whittlu je prikazana u tabeli 3 i na slici 8 .

Određivanje dinamike otkopavanja u NPVS-u omogućuje da se uz "primarni" limit (target) na preradi rude i "sekundarni" limit (tracking), odnosno praćenje (ba- lansiranje) ukupnih količina iskopina po godinama, odredi dinamika koja tačno prati glavni limit, ali zato samo približno prati iskopine. Program pokušava da nađe idealan scenario i u nemogućnosti da ga pronađe počinje postupno da opušta sekundarni limit (relaxing) dok ne ostvari primarni cilj, tj. "target" limit. Dobijena dinamika otkopavanja u NPVS-u je prikazana u tabeli 4 i na slici 9.

Dinamike prikazane u tabelama 3 i 4 je dobijene su za slučaj otkopavanja kopa u tri zahvata, tj. dve faze i konačni kop, i sa limitiranim kapacitetima na otkopavanju iskopina i na preradi sulfidne rude. U oba slučaja se dolazi do jedne od mogućih varijanti za dinamiku otkopavanja koja se, po potrebi, može izmeniti promenom izabranih ili uvođenjem dodatnih faza (Pushbacks) ili sa izmenom limita.

Tabela 3. Dinamika otkopavanja u softveru Whittle

\begin{tabular}{|c|c|c|r|r|r|r|r|r|r|}
\hline $\begin{array}{c}\text { God./ } \\
\text { Period }\end{array}$ & Iskopine & $\begin{array}{c}\text { Oksidna } \\
\text { ruda }\end{array}$ & $\begin{array}{c}\text { Input to } \\
\text { Leach }\end{array}$ & $\begin{array}{c}\text { Sulfidna } \\
\text { ruda }\end{array}$ & $\begin{array}{c}\text { Input } \\
\text { to Mill }\end{array}$ & $\begin{array}{c}\text { RUDA } \\
\text { (ukupno) }\end{array}$ & JALOVINA & $\begin{array}{c}\text { Koef. } \\
\text { raskri- } \\
\text { vke }\end{array}$ & NPV \\
\hline & $t$ & $t$ & \multicolumn{1}{c|}{ Cu\% } & $t$ & $C u \%$ & $t$ & $t$ & & $\$$ \\
\hline 1 & 17000000 & 3719981 & 0.24 & 1111045 & 0.37 & 4831026 & 12168974 & 2.52 & 4836966 \\
\hline 2 & 17000000 & 4792264 & 0.31 & 2496350 & 0.45 & 7288615 & 9711385 & 1.33 & 40597954 \\
\hline 3 & 17000000 & 4068033 & 0.23 & 5499785 & 0.36 & 9567818 & 7432182 & 0.78 & 41462231 \\
\hline 4 & 17000000 & 6350167 & 0.21 & 5283643 & 0.29 & 11633810 & 5366190 & 0.46 & 35248060 \\
\hline 5 & 17000000 & 1666371 & 0.20 & 5422840 & 0.28 & 7089211 & 9910789 & 1.4 & 8107899 \\
\hline 6 & 17000000 & 4368596 & 0.20 & 5499436 & 0.23 & 9868032 & 7131968 & 0.72 & 15347140 \\
\hline 7 & 10053699 & 1551532 & 0.18 & 5500000 & 0.23 & 7051532 & 3002167 & 0.43 & 8416079 \\
\hline 8 & 5406091 & 169693 & 0.19 & 4907900 & 0.24 & 5077594 & 328498 & 0.06 & 9271679 \\
\hline Total & $\mathbf{1 1 7 4 5 9 7 9 0}$ & $\mathbf{2 6 6 8 6 6 3 7}$ & & $\mathbf{3 5 7 2 0 9 9 9}$ & & $\mathbf{6 2 ~ 4 0 7 6 3 8}$ & $\mathbf{5 5 0 5 2} \mathbf{1 5 3}$ & $\mathbf{0 . 8 8}$ & $\mathbf{1 6 3 2 8 8 0 0 8}$ \\
\hline
\end{tabular}




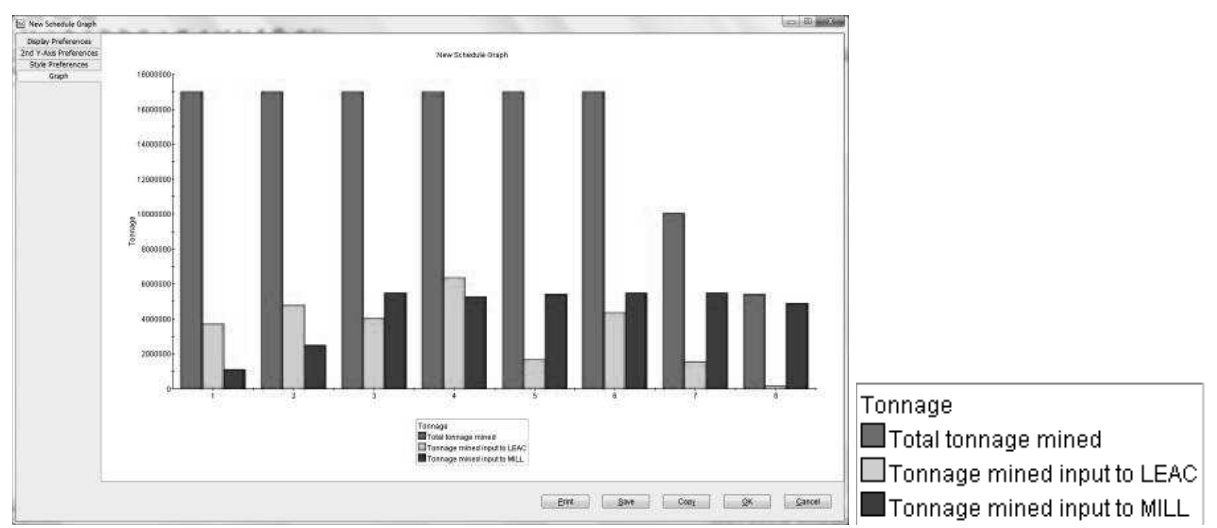

SI. 8. Grafički prikaz dinamike otkopavanja u softveru Whittle

Tabela 4. Dinamika otkopavanja u softveru NPVS

\begin{tabular}{|c|c|c|c|c|c|c|c|c|c|}
\hline $\begin{array}{c}\text { God./ } \\
\text { Period }\end{array}$ & Iskopine & $\begin{array}{c}\text { Oksidna } \\
\text { ruda }\end{array}$ & $\begin{array}{c}\text { Input } \\
\text { to } \\
\text { Leach }\end{array}$ & $\begin{array}{c}\text { Sulfidna } \\
\text { ruda }\end{array}$ & $\begin{array}{c}\text { Input } \\
\text { to Mill }\end{array}$ & $\begin{array}{c}\text { RUDA } \\
\text { (ukupno) }\end{array}$ & JALOVINA & $\begin{array}{c}\text { Koef. } \\
\text { raskrivke }\end{array}$ & NPV \\
\hline & $t$ & $t$ & $C u \%$ & $t$ & $C u \%$ & $t$ & $t$ & & \\
\hline 1 & 17003250 & 3020625 & 0.25 & 1266300 & 0.43 & 4286925 & 12716325 & 2.97 & 1375127 \\
\hline 2 & 16967812 & 4488750 & 0.30 & 2503575 & 0.47 & 6992325 & 9975487 & 1.43 & 37055864 \\
\hline 3 & 16707262 & 4995000 & 0.27 & 5499900 & 0.37 & 10494900 & 6212362 & 0.59 & 52671121 \\
\hline 4 & 16500712 & 6572813 & 0.22 & 5498550 & 0.31 & 12071362 & 4429350 & 0.37 & 40169189 \\
\hline 5 & 13000500 & 1282500 & 0.22 & 5501250 & 0.29 & 6783750 & 6216750 & 0.92 & 13289510 \\
\hline 6 & 13688662 & 2244375 & 0.21 & 5499900 & 0.25 & 7744275 & 5944387 & 0.77 & 11529474 \\
\hline 7 & 13568175 & 3155625 & 0.19 & 5498550 & 0.24 & 8654175 & 4914000 & 0.57 & 10330821 \\
\hline 8 & 4792500 & 160313 & 0.17 & 4058438 & 0.23 & 4218750 & 573750 & 0.14 & 5465836 \\
\hline Total & $\mathbf{1 1 2} \mathbf{2 2 8} \mathbf{8 7 4}$ & $\mathbf{2 5 9 2 0 0 0 0}$ & & $\mathbf{3 5 3 2 6 4 6 2}$ & & $\mathbf{6 1 2 4 6 4 6 2}$ & $\mathbf{5 0 9 8 2 4 1 2}$ & $\mathbf{0 . 8 3}$ & $\mathbf{1 7 1} \mathbf{8 8 6} \mathbf{9 4 1}$ \\
\hline
\end{tabular}

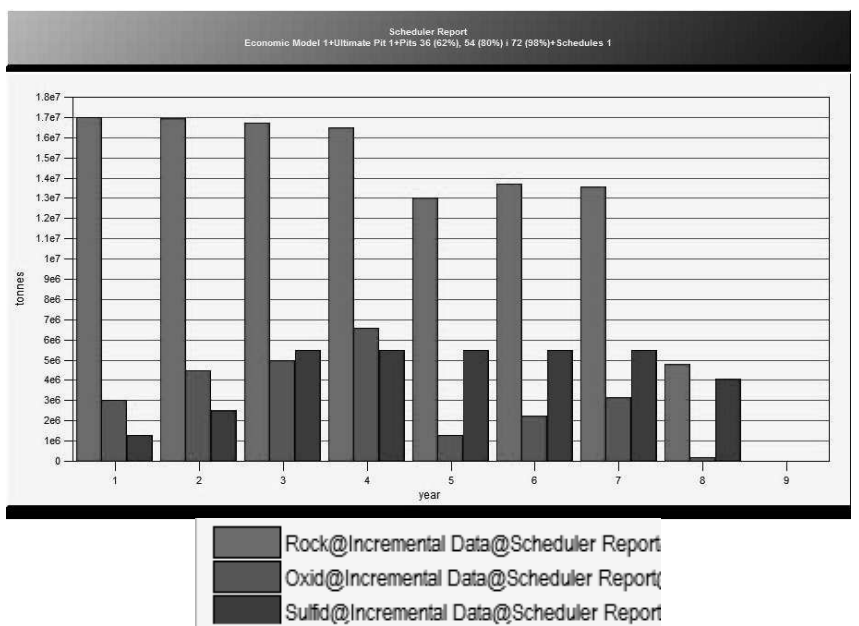

SI. 9. Grafički prikaz dinamike otkopavanja u softveru NPVS 
Razlika u aproksimaciji ugla u primenjenim softverima dovela je do određene razlike između količina rude i jalovine što je izazvalo da softveri "biraju” nešto drugačije najekonomičnije konture za odabrane revenue faktore. Ovo je dovelo do toga se pored razlike $\mathrm{u}$ količinama rude $\mathrm{u}$ konačnim konturama, javi i razlika u srednjem sadržaju bakra u dinamici otkopavanja, što je prikazano u tabelama 3 i 4 i na slici 10.

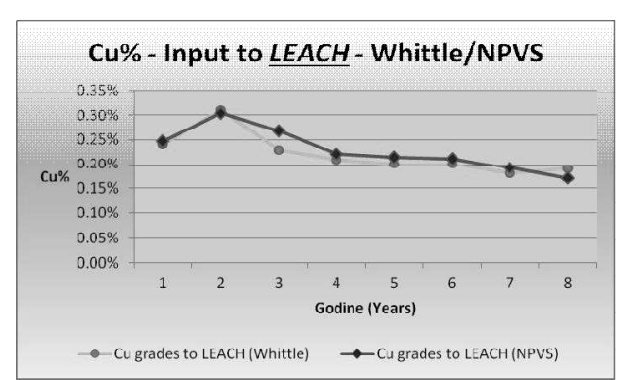

a.

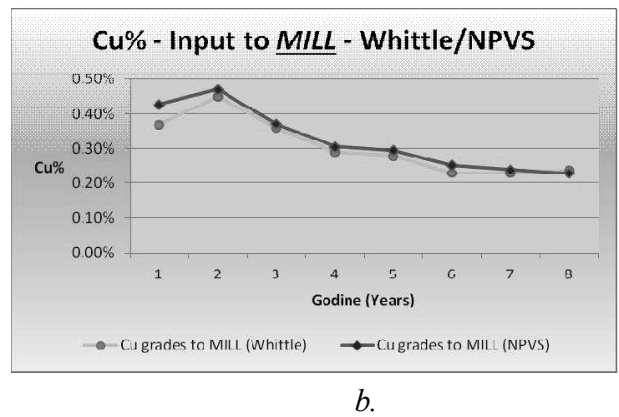

Sl. 10. Odnos srednjeg sadržaja bakra u ulaznoj rudi u procese LEACH (a) $i$ MILL (b) po godinama dinamike u softverima Whittle i NPVS

U tabeli 5 prikazane su količine dobijenog (recovered) metala kao finalnog proizvoda u konačnim konturama Whittla i NPVSa. Obzirom na veće količine rude i na iste tehnološke parametre prerade rude i dobijanja metala, dobijene su nešto veće količine finalnog proizvoda u slučaju konture dobijene u softveru Whittle.

Tabela 5. Količine dobijenog metala u konturama Whittle i NPVS

\begin{tabular}{|l|c|c|c|c|c|c|c|c|c|}
\hline \multirow{2}{*}{} & \multicolumn{6}{|c|}{ Oxid (proces LEACH) } & \multicolumn{2}{|c|}{ Sulfide (proces MILL) } & \multicolumn{3}{c|}{ Total } \\
\cline { 2 - 10 } & $\mathrm{Cu}$ & $\mathrm{Au}$ & $\mathrm{Ag}$ & $\mathrm{Cu}$ & $\mathrm{Au}$ & $\mathrm{Ag}$ & $\mathrm{Cu}$ & $\mathrm{Au}$ & $\mathrm{Ag}$ \\
\cline { 2 - 10 } & $\mathrm{t}$ & $\mathrm{kg}$ & $\mathrm{kg}$ & $\mathrm{t}$ & $\mathrm{kg}$ & $\mathrm{kg}$ & $\mathrm{t}$ & $\mathrm{kg}$ & $\mathrm{kg}$ \\
\hline Whittle & 46.337 & 907 & 11.335 & 81.260 & 1.442 & 15.838 & $\mathbf{1 2 7 . 5 9 7}$ & $\mathbf{2 . 3 4 9}$ & $\mathbf{2 7 . 1 7 3}$ \\
\hline NPVS & 44.869 & 875 & 10.828 & 80.185 & 1.419 & 15.557 & $\mathbf{1 2 5 . 0 5 4}$ & $\mathbf{2 . 2 9 4}$ & $\mathbf{2 6 . 3 8 5}$ \\
\hline
\end{tabular}

\section{ZAKLJUČAK}

Zbog različite procedure podešavanja parametara neophodnih za optimizaciju, u ovom slučaju izbor odgovarajućeg filtera ili broja etaža za aproksimaciju ugla kosine boka kopa, javila se određena razlika u količinama rude i iskopina koja je dovela do razlike u NPVu između ova dva slučaja. Ono što se moglo očekivati je da je kop sa, iako nešto manjim količinama rude, ali i povoljnijim koeficijentom raskrivke (Stripping Ratio) rezultovao sa većim NPV profitom. Takođe, barem u ovom slučaju, se pokazalo da je višak rude u konturi iz Whittla doveo do smanjenja srednjeg sadržaja bakra u dinamici otkopavanja $\mathrm{u}$ odnosu na konturu iz softvera NPVS, što je dodatno uticalo na razliku u NPVu. Obzirom na relativno male razlike, primenom oba softvera dolazi se do zadovoljavajućih rezultata u pogledu dinamike otkopavanja. Samim tim jedan softver može da posluži za proveru dobijenih rezultata iz drugog softvera $i$, eventualno, za poboboljšanje dinamike otkopavanja. 


\section{LITERATURA}

[1] Z. Vaduvesković, N. Vušović, D. Kržanović: Analiza mogućnosti poboljšanja ekonomskih pokazatelja eksploatacije ležišta Cementacija Kraku Bugaresku rudno polje Cerovo, Mining and Metallurgy Engineering Bor 1/2014, str. 25-36.

[2] K. Dagdelen, Open Pit Optimization Strategies for Improving Economics of Mining Projects Through Mine Planning, $17^{\text {th }}$ International Mining Congress and Exhibition of TurkeyIMCET2001, 2001.

[3] A. Hajarian, R. Dambov, R. Karanakova Stefanovska: Long term production scheduling of Sungun copper mine using NPV Scheduler software, $22^{\text {nd }}$ World Mining Congress and Expo, Istanbul 2011.

[4] M. L. Smith: Using Milawa/4X as a Starting Solution for Mixed Integer Programming Optimisation of Large Open Cut Production Schedules, Strategic Mine Planning Conference 2001

[5] M. E. Schlesinger, M. J. King, K. C. Sole, W. G. Dav enport: Extractive

metallurgy of copper fifth edition, 2011.

[6] G. A. Kordosky: Copper recovery using leach/solvent extraction/electrowinning technology: Forty years of innovation, 2.2 million tonnes of copper annually, The Journal of The South African Institute of Mining and Metallurgy, 2002

[7] K. Lee, D. Archibald, J. McLean, M. A. Reuter: Flotation of mixed copper oxide and sulphide minerals with xanthate and hydroxamate collectors, Mineral Engineering 2008

[8] Reference Manual, Four-X Strategic Planning Software for Open Pit Mines, Whittle Programming Pty Ltd, 1998

[9] http://rtb.rs/rtb-bor-doo/rudnik-bakrabor/rudnik-bakra-cerovo/

[10] Z. Vaduvesković, N. Vušović, D. Kržanović: Analiza mogućnosti poboljšanja ekonomskih pokazatelja eksploatacije ležišta cementacija Kraku Bugaresku rudno polje Cerovo, Mining and Metallurgy Institute Bor 1/2014, str. 25-36. 